\title{
Rasio Keuangan: Studi Komparasi Pada Perusahaan Industri Manufaktur dan Sektor Jasa Yang Melakukan Initial Public Offerings (IPO) Tahun 2018
}

\author{
T. Husain ${ }^{1)}$ \& Elvia Puspa Dewi ${ }^{2)}$ \\ 1)dosen STMIK Widuri Jakarta,email:thusain050686@gmail.com \\ ${ }^{2)}$ dosen STIE International Golden Institute Jakarta,email:elviapuspa2018@gmail.com
}

\section{ARTICLES}

INFORMATION

ABSTRACT

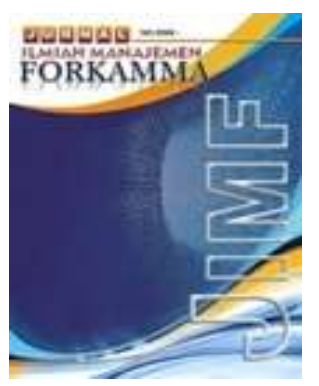

JURNAL ILMIAH MANAJEMEN FORKAMMA

Vol.3, No.2, Maret 2020

Halaman :131 - 141

(c) LPPM \& FORKAMMA

Prodi Magister Manajemen UNVERSITAS PAMULANG

ISSN (online) : 2599-171X

ISSN (print) : :2598-9545

\section{Keyword :}

Financial ratio's, IPO, liquidity ratio, solvency ratio, market ratio

JEL. classification :

C38, G20, G23, N65

\section{Contact Author : \\ PRODI \\ MAGISTER MANAJEMEN \& FORKAMMA UNPAM \\ JL.Surya Kencana No.1 Pamulang \\ Tangerang Selatan - Banten \\ Telp. (021) 7412566, Fax (021) 7412491 \\ Email: \\ jurnalforkamma.unpam@gmail.com}

Tujuan dari penelitian ini adalah untuk menjelaskan bagaimana signifikansi perbedaan rasio keuangan perusahaan industri manufaktur dan sektor jasa yang melakukan initial public offerings (IPO) tahun 2018. Rasio keuangan menggunakan 5 (lima) pengukuran yaitu rasio likuiditas, rasio aktivitas, rasio solvabilitas, rasio profitabilitas dan rasio prospek pasar dengan masingmasing proksi current ratio, total asset turnover, debt-to equity ratio, return on assets dan price-to book value. Sampel penelitian melibatkan 32 perusahaan yang diperoleh melalui metode purposive sampling. Metode analisis data menggunakan uji statistik dengan teknik Independent Sample T-Test dan Mann Whitney Test. Hasil penelitian menunjukkan bahwa rasio likuiditas, rasio solvabilitas dan rasio prospek pasar perusahaan industri manufaktur dan sektor jasa memiliki perbedaan yang signifikan sedangkan rasio aktivitas dan profitabilitas tidak memiliki perbedaan yang signifikan.

This research aim to explains how the significance of differences financial ratio's in manufacturing industry and service sectors company who do the initial public offerings (IPO) in 2018. Financial ratio's using 5 (five) measurements i.e. liquidity ratios, activity ratios, solvency ratios, profitability ratios and market prospect ratios with each current ratio, total asset turnover, debt-to equity ratio, return on assets and price-to-book value. The research sample involved 32 companies that were obtained through a purposive sampling method. The methods analysis uses statistical tests with the Independent Sample T-Test and Mann Whitney Test techniques. The results showed that the liquidity ratios, solvency ratios and market prospect ratios of the manufacturing industry and services sector have a significant differences while the activity ratios and profitability ratios didn't have significant differences. 


\section{A. PENDAHULUAN}

Nilai perusahaan merupakan hal yang mendasar dan penting bagi perusahaan yang sahamnya telah go public berdasarkan harga sahamnya. Investor akan memberikan penilaian berdasarkan harga pasar (market price) kepada suatu perusahaan. Setiap peningkatan kinerja operasional dan kinerja keuangan umumnya pada perusahaan publik akan berdampak terhadap harga saham di bursa yang pada akhirnya akan meningkatkan nilai perusahaan secara keseluruhan. Sejak bergabungnya Indonesia dalam Masyarakat Ekonomi ASEAN (MEA) pada tahun 2015 yang merupakan realiasasi pasar bebas di Asia Tenggara memiliki dampak positif kepada investor. Di sisi lain, Pemerintah menghadapi Revolusi Industri 4.0 menetapkan langkah strategis yaitu dengan optimalisasi kebijakan zona-zona industri dengan menyelaraskan peta jalan sektor-sektor industri yang menjadi fokus dalam Making Indonesia 4.0 (Kementerian Perindustrian Republik Indonesia, 2018). Kondisi ini tentunya menjadi kabar gembira bagi perusahaan-perusahaan publik dan yang akan melakukan Initial Public Offering (IPO). Rilis dari berita CNBC Indonesia mencatat sejarah baru bahwa sejak privatisasi pada tahun 1992, selama tahun 2018 hingga awal November 2018 terdapat 50 (lima puluh) emiten baru yang menjadi rekor pencatatan saham di Bursa Efek Indonesia (BEI) (Wareza, 2018).

Kinerja keuangan merupakan capaian prestasi perusahaan pada suatu periode yang merepresentasikan kesehatan keuangan perusahaan dengan indikator rasio keuangan tertentu meliputilikuiditas, profitabilitas dan kecukupan modal (Arisanti \& Bayangkara, 2016).Kinerja mengukur kesehatan keuangan dan kesehatan organisasi dalam hal moneter dan dapat digunakan untuk membandingkan kinerja berbagai perusahaan di dalam industri atau lintas sektor industri tertentu.Pengukuran kinerja perusahan dinilai dengan menggunakan metode analisis yang cukup populer dan digunakan baik akademisi maupun praktisi yaitu analisis rasio keuangan. Rasio keuangan diklasifikasikan ke dalam 5 (lima) kategori yaitu rasio likuiditas, rasio aktivitas, rasio solvabilitas, rasio profitabilitas dan rasio pasar. Analisis rasio keuangan diperlukan adanya data pembanding seperti standar industri atau data perusahaan lain.

Penelitian ini dilatarbelakangi oleh peneliti-peneliti terdahulu antara lain: (1) studi komparatif kinerja keuangan yang ditujukan untuk mengetahui seberapa besar signifikansi perbedaan rasio keuangan antara perusahaan domestik dengan perusahaan multinasional tahun 2013-2015 yang menggunakan variabel current ratio, fixed asset turnover, debt-to equity ratio, return on assets dan price-to book value melibatkan 50 sampel penelitian (Tiasita \& Wiagustini, 2017); (2) analisis perbandingan kinerja keuangan perusahaan telekomunikasi yang tercatat di BEI yaitu PT Telekomunikasi Indonesia Tbk dan PT Indosat, Tbk. periode 2006-2015 yang menggunakan variabel current ratio, debt to equity ratio, return on equity, return on asset, net profit margin, total asset turnover dan economic value added (EVA) (Ulum, Mardani, \& Wahono, 2017); dan (3) analisis perbandingan antara rasio keuangan dan metode economic value added sebagai pengukur kinerja keuangan yang melibatkan 4 (empat) perusahaan rokok yang terdaftar di BEI periode tahun 2012-2014 melibatkan variabel rasio likuiditas, rasio aktivitas, rasio solvabilitas, rasio profitabilitas dan economic value added (Arisanti \& Bayangkara, 2016). Ketiga hasil penelitian di atas memiliki beberapa keterbatasan, yaitu: (1) periode pengamatan yang digunakan belum secara konsisten menggunakan Standar Pelaporan Keuangan berbasis IFRS (International Financial Reporting Standard) yang diimplementasikan di Indonesia sejak tahun 2012; (2) penggunaan model pengukuran kinerja keuangan yang tidak terfokus pada pada salah satu pengukuran tertentu, seperti 5 (lima) rasio keuangan inti; dan (3) subjek penelitian tidak melibatkan perusahaanperusahaan yang melakukan penawaran saham perdana (IPO) sebagai starting-point pengukuran kinerja keuangan bagi perusahaan publik. 
Tujuan dari penelitian ini adalah melakukan komparasi analisis rasio keuangan dengan proksi inti seperti current ratio, activity ratio, solvency ratio, profitability ratio dan market ratio pada perusahaan industri manufaktur dan sektor jasa yang melakukan IPO di tahun 2018 karena portfolio ini sangat diminati oleh hampir seluruh investor dan calon investor yang akan mengambil keputusan investasi jangka panjang. Benchmark yang digunakan dalam pengukuran rasio keuangan ini diharapkan dapat lebih baik dan fokus untuk mengidentifikasi kategori perusahaan dengan kinerja rasio keuangan tertentu.

\section{B. KAJIAN LITERATUR}

Kajian literatur dituliskan dalam paragraf mengalir. Kajian literatur memaparkan tentang telaah dari berbagai referensi yang bersumber dari buku ilmiah umum, buku-buku teoritis, skripsi, tesis, disertasi dan jurnal ilmiah dan erat hubungannya dengan penelitian, penelitian sebelumnya berkaitan dengan judul penelitian, hipotesis penelitian. Selain itu kajian literatur berisi landasan teori yang ditampilkan dalam kalimat-kalimat lengkap, ringkas, serta benar-benar relevan dengan pendahuluan, tujuan penelitian. Sebagai contoh: Horngren dan Harrison (2017:4) menyatakan bahwa akuntansi merupakan sistem informasi yang mengukur aktivitas bisnis, memproses informasi menjadi laporan keuangan, dan mengkomunikan hasilnya kepada para pembuat pengambil keputusan.

Teori sinyal (signalling theory) diperkenalkan oleh Spence pada tahun 1973 yangmenjelaskan bahwa sinyal atau isyarat yang berasal dari pihak perusahaan sebagai pemilik informasi semaksimal mungkin akan memberikan informasi relevan yang dapat dimanfaatkan oleh pihak lainnya sebagai penerima informasi. Perusahaan mempunyai dorongan untuk memberikan informasi atas laporan keuangan pada pihak eksternal. Perusahaan diharapkan dapat memberikan informasi karena adanya asimetri informasi antara perusahaan dan pihak luar (investor dan regulator).Signalling theory merupakan suatu perilaku manajemen perusahaan dalam memberi petunjuk untuk investor terkait pandangan manajemen atas prospek perusahaan untuk masa mendatang. Sinyal dimaksud dapat berupa informasi yang menyatakan bahwa perusahaan tersebut dinyatakan lebih baik dari perusahaan lain (Brigham \& Houston, 2014).Informasi keuangan yang dirilis oleh perusahaan-perusahaan yang listing di BEI akan memberikan sinyal bagi investor yang terlebih dahulu dengan analisis dan interpretasi untuk pengambilan keputusan investasi.

Rasio lancar (current ratio) adalah salah satu rasio likuiditas yang menggambarkan kemampuan perusahaan dalam membayar kewajiban yang akanjatuh tempo (Subramanyam, 2014, hal. 546), semakin tinggi rasio ini berarti semakin terjamin hutang-hutang perusahaan kepada kreditur.Rasio perputaran aset (total asset turnover) adalah salah satu rasio aktivitas yang digunakan untuk mengukur seberapa besar efektivitas perusahaan dalam menggunakan sumber daya yang berupa aset (Brigham \& Houston, 2014, hal. 39), semakin tinggirasio iniberarti semakin efektif perusahaan dalam mengelola asetnya.Rasio leverage (debt-to equity ratio) adalah salah satu rasio solvabilitas yang merefleksikan jumlah pendanaan utang dalam struktur modal suatu perusahaan (Subramanyam, 2014, hal. 565), semakin rendah rasio ini berarti semakintinggi kemampuan perusahaanuntuk membayar seluruh kewajibannya.Rasio tingkat pengembalian aset (return on asset ratio) adalah salah satu rasio profitabilitas yang digunakan untuk mengukur kemampuan perusahaan dalam menghasilkan keuntungan dengan seluruh aset yang dimilikinya (Titman, Keown, \& Martin, 2018, hal. 11).Rasio harga perolehan (price to book value) adalah salah satu rasio prospek pasar yang digunakan untuk melihat pengakuan pasar terhadap nilai pasar saham suatu perusahaan (Murhadi, 2015, hal. 66), semakin tinggi rasio ini berarti semakin tinggi minat investor untuk membeli saham tersebut. 


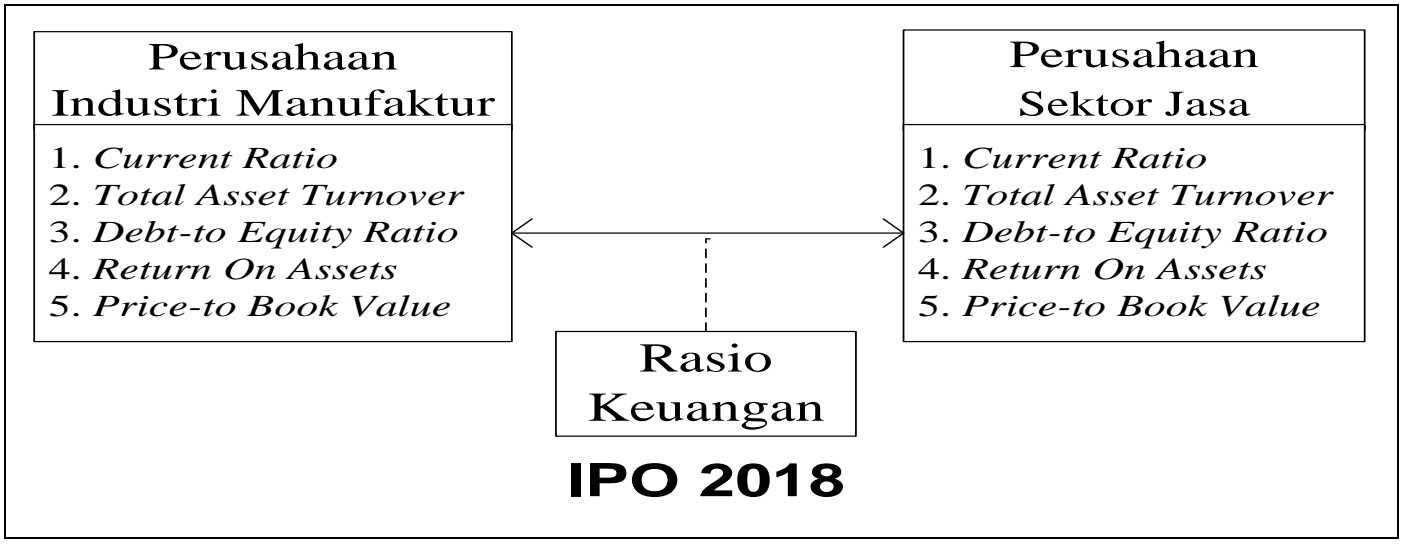

Sumber: Dikembangkan untuk penelitian ini

Gambar 1. Model Penelitian

Berdasarkan rancangan model penelitian di atas, hipotesis penelitian ini dirumuskan sebagai berikut:

$\mathrm{H}_{0}$ : Tidak terdapat perbedaan yang signifikan antara perusahaan industri manufaktur dan sektor jasa yang melakukan IPO tahun 2018 terhadap masing-masing rasio keuangan.

$\mathrm{H}_{1}$ : Terdapat perbedaan yang signifikan antara perusahaan industri manufaktur dan sektor jasa yang melakukan IPO tahun 2018 terhadap current ratio.

$\mathrm{H}_{2}$ : Terdapat perbedaan yang signifikan antara perusahaan industri manufaktur dan sektor jasa yang melakukan IPO tahun 2018 terhadap total asset turnover.

$\mathrm{H}_{3}$ : Terdapat perbedaan yang signifikan antara perusahaan industri manufaktur dan sektor jasa yang melakukan IPO tahun 2018 terhadap debt-to equity ratio.

$\mathrm{H}_{4}$ : Terdapat perbedaan yang signifikan antara perusahaan industri manufaktur dan sektor jasa yang melakukan IPO tahun 2018 terhadap return on asset.

$\mathrm{H}_{5}$ : Terdapat perbedaan yang signifikan antara perusahaan industri manufaktur dan sektor jasa yang melakukan IPO tahun 2018 terhadap price-to book value.

\section{METODOLOGI PENELITIAN}

Metode penelitian merupakan tahapan atau cara ilmiah untuk mendapatkan data dengan tujuan dan keguanaan tertentu (Sugiyono, 2018, hal. 2). Jenis penelitian menggunakan pendekatan kuantitatif dengan studi komparasi.Penelitian komparasi dimaksudkan dengan tujuan untukmembandingkan kondisi yang terdapat di 2 (dua) tempat, apakah kedua kondisi tersebut sama atau terdapat perbedaan, jika ditemukan perbedaan, kondisi di tempat mana yang lebih baik (Arikunto, 2013, hal. 6). Populasi dalam penelitian ini adalah perusahaan-perusahaan yang terdaftar di BEl yang melakukan IPO selama tahun 2018. Teknik penentuan sampel menggunakan metode purposive sampling yaitu teknik penentuan sampel dengan pertimbangan tertentu (Sugiyono, 2018, hal. 126) dengan syarat: (1) perusahaan industri manufaktur dan sektor jasa yang melakukan IPO tahun 2018; dan (2) perusahaan menyediakan informasi yang lengkap tentang rasio keuangan. Sampel penelitian ditetapkan sebanyak 32 (tiga puluh dua) perusahaan.

Tabel 1. Sampel Penelitian

\begin{tabular}{ccc}
\hline $\begin{array}{c}\text { Kode } \\
\text { Emiten }\end{array}$ & Nama Perusahaan & Tanggal IPO \\
\hline INPS & PT Indah Prakasa Sentosa, Tbk. & $06-A p r-2018$ \\
TDPM & PT Tridomain Perfomance Materials, Tbk. & $09-A p r-2018$ \\
DFAM & PT Dafam Property Indonesia, Tbk. & $27-A p r-2018$
\end{tabular}


SPTO

PRIM

HEAL

PZZA

KPAL

SWAT

MSIN

TCPI

NUSA

NFCX

FILM

MOLI

DIGI

PANI

SAPX

KPAS

HKMU

GOOD

DUCK

YELO

CAKK

SOSS

DEAL

DIVA

LUCK

SOTS

URBN

ZONE

PEHA
PT Surya Pertiwi, Tbk.

PT Royal Prima, Tbk.

PT Medikaloka Hermina, Tbk.

PT Sarimelati Kencana, Tbk.

PT Steadfast Marine, Tbk.

PT Sriwahana Adityakarta, Tbk.

PT MNC Studios International, Tbk.

PT Transcoal Pacific, Tbk.

PT Sinergi Megah Internusa, Tbk. PT NFC Indonesia, Tbk.

PT MD Pictures, Tbk.

PT Madusari Murni Indah, Tbk.

PT Arkadia Digital Media, Tbk.

PT Pratama Abadi Nusa Industri, Tbk.

PT Satria Antaran Prima, Tbk.

PT Cottonindo Ariesta, Tbk.

PT HK Metals Utama, Tbk.

PT Garudafood Putra Putri Jaya, Tbk.

PT Jaya Bersama Indo, Tbk.

. PT Yelooo Integra Datanet, Tbk.

PT Cahayaputra Asa Keramik, Tbk.

PT Shield On Services, Tbk.

PT Dewata Freight International, Tbk.

PT Distribusi Voucher Nusantara, Tbk.

PT Sentral Mitra Informatika, Tbk.

PT Satria Mega Kencana, Tbk.

PT Urban Jakarta Propertindo, Tbk.

PT Mega Perintis, Tbk.

PT Phapros, Tbk.

Jumlah
14-Mei-2018

15-Mei-2018

16-Mei-2018

23-Mei-2018

08-Jun-2018

08-Jun-2018

08-Jun-2018

06-Jul-2018

12-Jul-2018

12-Jul-2018

07-Agus-2018

30-Agus-2018

18-Sept-2018

18-Sept-2018

03-Okt-2018

05-Okt-2018

09-Okt-2018

10-Okt-2018

10-Okt-2018

29-Okt-2018

31-Okt-2018

06-Nov-2018

09-Nov-2018

27-Nov-2018

28-Nov-2018

10-Des-2018

10-Des-2018

12-Des-2018

26-Des-2018

32

Sumber: Bursa Efek Indonesia (2019)

Tabel 2. Variabel Operasional

\begin{tabular}{|c|c|c|c|}
\hline Variabel & Proksi & Ukuran Rasio & Skala \\
\hline Rasio Likuiditas & Current Ratio & $\frac{\text { Current Asset }}{\text { Current Liabilities }}$ & Rasio \\
\hline Rasio Aktivitas & $\begin{array}{c}\text { Total Asset Turnover } \\
\text { Ratio }\end{array}$ & $\frac{\text { Net Sales }}{\text { Average Total Asset }}$ & Rasio \\
\hline Rasio Solvabilitas & Debt-to Equity Ratio & $\frac{\text { Total Liabilities }}{\text { Stakeholders' Equity }}$ & Rasio \\
\hline Rasio Profitabilitas & Return On Assets & $\frac{\text { Net Income }}{\text { Total Asset }}$ & Rasio \\
\hline $\begin{array}{c}\text { Rasio Prospek } \\
\text { Pasar }\end{array}$ & Price-to Book Value & $\begin{array}{c}\text { Market Shares } \\
\text { Book Value Shares }\end{array}$ & Rasio \\
\hline
\end{tabular}

Metode analisis data dalam penelitian ini menggunakan pendekatan uji beda t-test. Uji beda t-test digunakan untuk menentukan apakah (2) dua sampel yang tidak berhubungan memiliki nilai rata-rata yang berbeda dibandingkan dengan standar error (Ghozali, 2017, hal. 64). Pengujian ini mensyaratkan kelayakan model melalui uji normalitas data dan homogenitas terlebih dahulu, jika salah satu atau kedua karakteristik dari pengujian di atas tidak berdistribusi normal atau berasal dari varians yang sama maka alternatif uji statistik non-parametrik dengan Mann-Whitney Tests dapat digunakan (Uyanto, 2009, hal. 321). Untuk mengintepretasikan uji t-test terlebih dahulu menentukan nilai a dan degree of freedom (df) dan membandingkan nilai t-hitung dengan t-tabel. Probabilitas signifikansi yang ditetapkan dalam penelitian ini adalah 0,05 dengan kriteria 
penerimaan hipotesis yaitu jika nilai t-hitung lebih besar dari $t$-tabel $\left(\mathrm{H}_{0}\right.$ diterima), atau sebaliknya jika nilai t-hitung lebih kecil dari t-tabel ( $\mathrm{H}_{\mathrm{a}}$ diterima).

\section{HASIL DAN PEMBAHASAN}

1. Analisis Statistik Deskriptif

Tabel 3. Statistik Deskriptif

Descriptive Statistics

\begin{tabular}{|l|r|r|r|r|r|}
\hline & $\mathrm{N}$ & Minimum & Maximum & \multicolumn{1}{c|}{ Mean } & \multicolumn{1}{c|}{ Std. Deviation } \\
\hline Current Ratio & 32 &, 3548 & 17,2435 & 3,138750 & 3,3873873 \\
Total Asset Turn Over & 32 &, 0124 & 2,1880 &, 408856 &, 4330149 \\
Debt-to Equity Ratio & 32 &, 0275 & 3,4005 &, 867706 &, 8802380 \\
Return on Assets & 32 &,- 3135 &, 1900 &, 035675 &, 0838180 \\
Price-to Book Value & 32 &, 10 & 18,90 & 4,7981 & 5,00566 \\
Valid N (listwise) & 32 & & & & \\
\hline
\end{tabular}

Sumber: Output SPSS 24.00 (2019)

"Deskripsi Statatistik mekanisme good corporate governance terhadap nilai perusahaan dengan leverage sebagai variabel intervening pada perusahaan manufaktur yang tercatat di IDX (Indonesia Stock Exchange) selama priode 2012-2018 adalah sbb" :

2. Uji Normalitas dan Homogenitas

Tabel 4. Hasil Uji Normalitas

\begin{tabular}{|ll|r|r|r|r|r|r|}
\hline & & \multicolumn{3}{c|}{ Tests of Normality } \\
& Kategori Industri & \multicolumn{2}{c|}{ Kolmogorov-Smirnov } & \multicolumn{3}{|c|}{ Shapiro-Wilk } \\
\cline { 3 - 8 } & Statistic & \multicolumn{1}{c|}{ df } & \multicolumn{1}{c|}{ Sig. } & Statistic & \multicolumn{1}{c|}{ df } & Sig. \\
\hline \multirow{2}{*}{ Current Ratio } & Manufaktur &, 334 & 12 &, 001 &, 613 & 12 &, 000 \\
& Sektor Jasa &, 241 & 20 &, 004 &, 745 & 20 &, 000 \\
Total Asset Turn Over & Manufaktur &, 281 & 12 &, 010 &, 610 & 12 &, 000 \\
& Sektor Jasa &, 260 & 20 &, 001 &, 863 & 20 &, 009 \\
Debt-to Equity Ratio & Manufaktur &, 209 & 12 &, 156 &, 815 & 12 &, 014 \\
& Sektor Jasa &, 219 & 20 &, 013 &, 735 & 20 &, 000 \\
Return on Assets & Manufaktur &, 169 & 12 &, 200 &, 895 & 12 &, 138 \\
& Sektor Jasa &, 192 & 20 &, 051 &, 838 & 20 &, 003 \\
Price-to Book Value & Manufaktur &, 261 & 12 &, 023 &, 771 & 12 &, 004 \\
& Sektor Jasa &, 232 & 20 &, 006 &, 858 & 20 &, 007 \\
\hline
\end{tabular}

*. This is a lower bound of the true significance.

a. Lilliefors Significance Correction

Sumber: Output SPSS 24.00 (2019)

Hasil uji normalitas pada uji Shapiro-Wilk pada kategori perusahaan industri manufaktur dan sektor jasa menghasilkan p-value kurang dari 0,05 atas hampir keseluruhan variabel yang diteliti $\left(\mathrm{H}_{0}\right.$ ditolak) yang berarti data tidak berdistribusi normal, kecuali variabel ROA pada kategori industri manufaktur dengan $p$-value sebesar 0,138 $\left(\mathrm{H}_{0}\right.$ diterima) yang berarti data berdistribusi normal.

Uji homogenitas bertujuan untuk mengetahui apakah homogen atau tidaknya data dalam suatu penelitian kemudian untuk menentukan langkah berikutnya mengenai jenis metode statistik yang digunakan apakah menggunakan parametrics test atau non-parametrics tests. Pengujian ini menggunakan teknik Levene's (Levene Statistic). Jika probabilitas signifikansi lebih besar sama dengan ( $\geq$ ) 0,05 maka data sampel berasal dari populasi yang mempunyai varians yang sama atau homogen $\left(\mathrm{H}_{0}\right.$ diterima), atau sebaliknya. 
Tabel 5. Hasil Uji Homogenitas

Test of Homogeneity of Variances

\begin{tabular}{|l|r|r|r|r|}
\hline & Levene Statistic & df1 & df2 & \multicolumn{1}{c|}{ Sig. } \\
\hline Current Ratio & 3,630 & 1 & 30 &, 066 \\
Total Asset Turn Over &, 390 & 1 & 30 &, 537 \\
Debt-to Equity Ratio &, 120 & 1 & 30 &, 731 \\
Return on Assets & 3,045 & 1 & 30 &, 091 \\
Price-to Book Value & 17,806 & 1 & 30 &, 000 \\
\hline
\end{tabular}

Sumber: Output SPSS 24.00 (2019)

Hasil uji homogenitas menunjukkan bahwa variabel CR, TATO, DER, dan ROA memiliki nilai probabilitas signifikansi lebih besar dari 0,05 , artinya rasio keuangan antara perusahaan pada industri manufaktur dan sektor jasa mempunyai varians yang sama atau berasal dari populasi yang homogen. Variabel PBV memiliki nilai probabilitas signifikansi sebesar 0,000 $(<0,05)$, artinya rasio keuangan antara perusahaan pada industri manufaktur dan sektor jasa mempunyai varians yang tidak sama atau atau berasal dari populasi yang heterogen.

Berdasarkan hasil uji normalitas dan homogenitas data dapat dirangkum alat statistik untuk menguji signifikansi perbedaan rasio keuangan kategori industri manufaktur dan sektor jasa berikut ini:

Tabel 6. Rangkuman Hasil Uji Normalitas dan Homogenitas

\begin{tabular}{cccc}
\hline Variabel & $\begin{array}{c}\text { Hasil Uji } \\
\text { Shapiro-Wilk }\end{array}$ & $\begin{array}{c}\text { Hasil Uji } \\
\text { Levene's Test }\end{array}$ & $\begin{array}{c}\text { Alat Statistik untuk } \\
\text { Uji Hipotesis }\end{array}$ \\
\hline CR & $. s i g<0,05$ & $. s i g>0,05$ & Mann Whitney Test \\
TATO & $. s i g<0,05$ & $. s i g>0,05$ & Mann Whitney Test \\
DER & $. s i g<0,05$ & $. s i g>0,05$ & Mann Whitney Test \\
ROA & $. s i g>0,05$ & $. s i g>0,05$ & Independent-Samples T Test \\
PBV &. sig $<0,05$ & $. s i g<0,05$ & Mann Whitney Test \\
\hline
\end{tabular}

Sumber: Data Diolah SPSS 24.00 (2019)

3. Uji Hipotesis

Uji hipotesis dilakukan dengan teknik t-tests dengan melihat pada kesamaan atau perbedaan rasio keuangan dengan rata-rata nilai current ratio, total asset turnover, debt-to equity ratio, return on assets, dan price-to book value. Setelah dilakukan uji normalitas dan homogenitas data, diperoleh keputusan untuk menggunakan alat statistik Mann Whitney Test untuk variabel rasio likuiditas, rasio aktivitas, rasio solvabilitas dan rasio pangsa pasar dengan kriteria penerimaan hipotesis sebagai berikut:

Tabel 7. Rangkuman Hasil Uji Mann Whitney Test

\begin{tabular}{lcccc}
\hline \multirow{1}{*}{ Variabel } & $\begin{array}{c}\text { Current } \\
\text { Ratio }\end{array}$ & $\begin{array}{c}\text { Total Asset } \\
\text { Turn Over }\end{array}$ & $\begin{array}{c}\text { Debt-to } \\
\text { Equity Ratio }\end{array}$ & $\begin{array}{c}\text { Price-to } \\
\text { Book } \\
\text { Value }\end{array}$ \\
\cline { 2 - 5 } & 11,68 & 15,92 & 21,25 & 12,17 \\
Mean Rank: & 19,28 & 16,85 & 13,65 & 19,10 \\
1. Industri Manufaktur & & 113 & 63 & 68 \\
2. Sektor Jasa & 64,5 & 0,785 & 0,027 & 0,043 \\
Mann-Whitney UScore & 0,031 & $-0,272$ & -2,219 & $-2,024$ \\
Sig. (2-tailed) & $-2,161$ & H2 Ditolak & H3 Diterima & H5 Diterima \\
Z-score & H1 Diterima & \multicolumn{3}{c}{}
\end{tabular}

Sumber: Data Diolah SPSS 24.00 (2019) 
Pembuktian uji hipotesis atas variabel rasio keuangan yang menggunakan alat statistik mann whitney test antara perusahaan industri manufaktur dengan sektor jasa yaitu:

Hipotesis ke-1: nilai Mann-Whitney untuk variabel current ratio diperoleh sebesar 64,5 dengan probabilitas signifikansi sebesar 0,031 pada pengujian kedua kategori perusahaan tersebut. Nilai signifikansi sebesar 0,002 lebih kecil dari $\alpha=5 \%$ sehingga menerima $\mathrm{H}_{1}$. Hipotesis ini secara statistik membuktikan bahwa terdapat perbedaan yang signifikan antara perusahaan industri manufaktur dan sektor jasa yang melakukan IPO tahun 2018 terhadap current ratio.

Hipotesis ke-2: nilai Mann-Whitney untuk variabel total asset turnover diperoleh sebesar 113 dengan probabilitas signifikansi sebesar 0,785 pada pengujian kedua kategori perusahaan tersebut. Nilai signifikansi sebesar 0,785 lebih besar dari $\alpha=5 \%$ sehingga menolak $\mathbf{H}_{\mathbf{2}}$. Hipotesis ini secara statistik membuktikan bahwa tidak terdapat perbedaan yang signifikan antara perusahaan industri manufaktur dan sektor jasa yang melakukan IPO tahun 2018 terhadap total asset turnover.

Hipotesis ke-3: nilai Mann-Whitney untuk variabel debt-to equity ratio diperoleh sebesar 63 dengan probabilitas signifikansi sebesar 0,027 pada pengujian kedua kategori perusahaan tersebut. Nilai signifikansi sebesar 0,027 lebih kecil dari $\alpha=5 \%$ sehingga menerima $\mathbf{H}_{3}$. Hipotesis ini secara statistik membuktikan bahwa terdapat perbedaan yang signifikan antara perusahaan industri manufaktur dan sektor jasa yang melakukan IPO tahun 2018 terhadap debt-to equity ratio.

Hipotesis ke-5: nilai Mann-Whitney untuk variabel price-to book value diperoleh sebesar 68 dengan probabilitas signifikansi sebesar 0,043 pada pengujian kedua kategori perusahaan tersebut. Nilai signifikansi sebesar 0,043 lebih kecil dari $\alpha=5 \%$ sehingga menerima $\mathbf{H}_{\mathbf{5}}$. Hipotesis ini secara statistik membuktikan bahwa terdapat perbedaan yang signifikan antara perusahaan industri manufaktur dan sektor jasa yang melakukan IPO tahun 2018 terhadap price-to book value.

Tabel 8. Hasil Uji Independent Samples T Test Test

Independent Samples Test

\begin{tabular}{|c|c|c|c|c|c|c|c|c|c|c|}
\hline & \multicolumn{2}{|c|}{$\begin{array}{l}\text { Levene's Test } \\
\text { for Equality of } \\
\text { Variances }\end{array}$} & \multicolumn{7}{|c|}{ t-test for Equality of Means } \\
\hline & & \multirow[t]{2}{*}{$\mathrm{F}$} & \multirow[t]{2}{*}{ Sig. } & \multirow[t]{2}{*}{$\mathrm{t}$} & \multirow[t]{2}{*}{$\mathrm{df}$} & \multirow[t]{2}{*}{$\begin{array}{c}\text { Sig. } \\
(2- \\
\text { tailed })\end{array}$} & \multirow[t]{2}{*}{$\begin{array}{c}\text { Mean } \\
\text { Difference }\end{array}$} & \multirow[t]{2}{*}{$\begin{array}{l}\text { Std. Error } \\
\text { Difference }\end{array}$} & \multicolumn{2}{|c|}{$\begin{array}{l}\text { 95\% Confidence } \\
\text { Interval of the } \\
\text { Difference }\end{array}$} \\
\hline & & & & & & & & & Lower & Upper \\
\hline $\begin{array}{l}\text { Return } \\
\text { on } \\
\text { Assets }\end{array}$ & $\begin{array}{l}\text { Equal } \\
\text { variances } \\
\text { assumed } \\
\text { Equal } \\
\text { variances not } \\
\text { assumed }\end{array}$ & 3,045 & ,091 & ,486 & 25,183 & ,696 & ,0122400 &, 0310316 & $\begin{array}{l}-, 0511349 \\
-, 0396298\end{array}$ & $\begin{array}{l}, 0756149 \\
, 0641098\end{array}$ \\
\hline
\end{tabular}

Sumber: Output SPSS 24.00 (2019)

Pembuktian uji hipotesis atas variabel rasio keuangan yang menggunakan alat statistik independent samples $t$ test antara perusahaan industri manufaktur dengan sektor jasa menghasilkan nilai F-hitung sebesar 3,046 dengan probabilitas signifikansi sebesar 0,091 lebih dari $0,05\left(\mathrm{H}_{0}\right.$ diterima). Oleh karena signifikansi $\mathrm{F}$ memiliki keputusan equal variance assumed maka uji t juga menggunakan equal variance assumed. Nilai t-hitung diperoleh 
sebesar 0,394 dengan probabilitas signifikansi lebih besar dari 0,05 sehingga menolak $\mathbf{H}_{4}$. Hipotesis ini secara statistik membuktikan bahwa tidak terdapat perbedaan yang signifikan antara perusahaan industri manufaktur dan sektor jasa yang melakukan IPO tahun 2018 terhadap return on assets.

\section{Pembahasan}

Penggunaan rasio keuangan yang terdiri dari rasio likuiditas, rasio aktivitas, rasio solvabilitas, rasio profitabilitas dan rasio prospek pasar dengan pengukuran current ratio, total asset turnover, debt-to equity ratio, return on asset dan price-to book value yang membandingkan kategori perusahaan industri manufaktur dan sektor jasa dapat menjadi pengukuran yang cukup akurat dan membuktikan teori pensinyalan (signalling theory) bagi calon investor atau publik untuk menganalisis dan menginterpretasi rasio keuangan sebagai dasar pengambilan keputusan investasi.

Rasio likuiditas dengan proksi current ratio dengan temuan hipotesis ke-1 menunjukkan bahwa terdapat perbedaan yang signifikan antara perusahaan kategori industri manufaktur dan sektor jasa. Temuan penelitian ini bertolak belakang, dimana tidak terdapat perbedaan rasio likuiditas (current ratio) antara perusahaan domestik dengan perusahaan multinasional yang terdaftar di BEI (Tiasita \& Wiagustini, 2017). Pengukuran rasio likuiditas untuk perusahaan sektor jasa dapat menggunakan quick ratio yang menunjukkan kemampuan perusahaan membayar kewajiban jangka pendek dengan aset lancar tanpa memperhitungkan nilai persediaan (Kasmir, 2016, hal. 136).

Rasio aktivitas dengan proksi total asset turnover dengan temuan hipotesis ke-2 menunjukkan bahwa tidak terdapat perbedaan yang signifikan antara perusahaan kategori industri manufaktur dan sektor jasa. Temuan penelitian ini juga mengkonfirmasi tidak terdapat perbedaan rasio aktivitas antara perusahaan domestik dengan perusahaan multinasional yang terdaftar di BEI menggunakan variabel fixed asset turnover (Tiasita \& Wiagustini, 2017). Pengukuran rasio aktivitas untuk perusahaan sektor jasa pada penelitian ini dinilai lebih efisen dalam pemanfaatan sumber daya perusahaan untuk melaksanakan aktivitas sehari - hari. (Murhadi, 2015, hal. 56).

Rasio solvabilitas dengan proksi debt-to equity ratio dengan temuan hipotesis ke-3 menunjukkan bahwa terdapat perbedaan yang signifikan antara perusahaan kategori industri manufaktur dan sektor jasa. Temuan penelitian ini juga bertolak belakang, dimana tidak terdapat perbedaan rasio solvabilitas antara perusahaan domestik dengan perusahaan multinasional yang terdaftar di BEI (Tiasita \& Wiagustini, 2017). Pengukuran rasio solvabilitas untuk perusahaan industri manufaktur dapat menggunakan debt-to equity ratio karena memiliki rata-rata nilai utang lancar perusahaan yang lebih besar dari nilai modal sendiri (Ulum, Mardani, \& Wahono, 2017).

Rasio profitabilitas dengan proksi return on assets dengan temuan hipotesis ke-4 menunjukkan bahwa tidak terdapat perbedaan yang signifikan antara perusahaan kategori industri manufaktur dan sektor jasa. Temuan penelitian ini juga mengkonfirmasi tidak terdapat perbedaan rasio aktivitas antara perusahaan domestik dengan perusahaan multinasional yang terdaftar di BEl yang juga menggunakan variabel return on assets (Tiasita \& Wiagustini, 2017). Pengukuran rasio profitabilitas untuk perusahaan industri manufaktur dan sektor jasa pada penelitian ini secara umum dapat dinilai berdasarkan tingkat pengembalian aset yang dimiliki perusahaan.

Rasio prospek pasar dengan proksi price-to book value dengan temuan hipotesis ke-5 menunjukkan bahwa terdapat perbedaan yang signifikan antara perusahaan kategori industri manufaktur dan sektor jasa. Temuan penelitian ini juga bertolak belakang, dimana tidak terdapat perbedaan rasio solvabilitas antara perusahaan domestik dengan perusahaan multinasional yang terdaftar di BEI (Tiasita \& Wiagustini, 2017). Pengukuran rasio prospek pasar menggunakan PBV pada penelitian ini memiliki perbedaan antara perusahaan industri manufaktur dan sektor jasa, hal ini dapat dipahami bahwa skor PBV 
hanya sekedar bertujuan memberikan informasi seberapa besar para pemegang saham menghargai perusahaan (Murhadi, 2015, hal. 56)

\section{E. KESIMPULAN}

Kesimpulan dari studi komparasi atas rasio keuangan antara perusahaan industri manufaktur dan sektor jasa yang melakukan initial public offerings (IPO) pada tahun 2018 yaitu terdapat perbedaan yang signifikan antara kedua kategori perusahaan di atas menggunakan rasio likuiditas, rasio solvabilitas dan rasio prospek pasar sedangkan rasio aktivitas dan rasio profitabilitas tidak memiliki perbedaan yang signifikan antara kedua kategori perusahaan. Penilaian atas likuiditas perusahaan untuk perusahaan sektor jasa dapat menggunakan pengukuran selain current ratio yang tanpa memperhitungkan nilai dari persediaan. Rasio solvabilitas dapat tetap menggunakan debt-to equity ratio dengan kombinasi debt-to asset ratio untuk mengukur sejauhmana aset perusahaan yang dibiayai dengan komponen utang. Rasio prospek pasar dapat menggunakan pengukuran lainnya seperti price-to earnings ratio (PER) atau pengukuran lainnya agar lebih dapat merepresentasikan untuk kategori-kategori perusahaan yang melakukan IPO. Penelitian selanjutnya diharapkan dapat menambahkan lebih proksi rasio keuangan lainnya untuk mengukur perbandingan kinerja keuangan pada perusahaan-perusahaan yang terdaftar di Bursa Efek Indonesia serta memperpanjang periode penelitian dengan komparasi sebelum dan setelah perusahaan melakukan IPO agar dapat lebih memperkaya hasil penelitian di masa mendatang.

\section{DAFTAR PUSTAKA}

Arikunto, S. (2013). Arikunto, Suharsimi. (2013). Prosedur Penelitian Suatu Pendekatan Praktik. Jakarta: Rineka Cipta.

Arisanti, A., \& Bayangkara, I. (2016). Analisis Perbandingan Antara Rasio Keuangan Dan Metode Economic Value Added Sebagai Pengukur Kinerja Keuangan Perusahaan (Studi Kasus Pada Perusahaan Rokok Yang Terdaftar Di BEI Periode Tahun 20122014. JEA17: Jurnal Ekonomi Akuntansi , 1 (1), 97-108.

Brigham, E. F., \& Houston, J. F. (2014). Dasar-Dasar Manajemen Keuangan. Jakarta: Salemba Empat.

Ghozali, I. (2017). Aplikasi Analisis Multivariate Dengan Program: IBM SPSS 23 (VIII ed.). Semarang: Badan Penerbit UNDIP.

Kasmir, D. (2016). Analisis Laporan Keuangan. Jakarta: PT. Rajagrafindo Persada.

Kementerian Perindustrian Republik Indonesia. (2018). Pemerintah Keluarkan 10 Jurus Jitu Hadapi Revolusi Industri 4.0. Dipetik Oktober 22, 2019, dari https://kemenperin.go.id/artikel/19169/Pemerintah-Keluarkan-10-Jurus-Jitu-HadapiRevolusi-Industri-4.0

Murhadi, W. R. (2015). Analisis Laporan Keuangan: Proyeksi dan Valuasi Saham. Jakarta: Salemba Empat.

Subramanyam, K. (2014). Financial Statement Analysis (11th International Edition ed.). New York: McGraw-Hill. 
Sugiyono. (2018). Metode Penelitian Evaluasi: Pendekatan Kuantitatif, Kualitatif, dan Kombinasi. Bandung: CV. Alfabeta.

Tiasita, N. K., \& Wiagustini, L. P. (2017). Studi Komparatif Kinerja Keuangan Pada Perusahaan Domestik Dan Perusahaan Multinasional. E-Jurnal Manajemen Unud, 6 (5), 2609-2641.

Titman, S., Keown, A. J., \& Martin, J. D. (2018). Financial Management: Principles and Applications. Boston: Prentice Hall.

Ulum, H., Mardani, R. M., \& Wahono, B. (2017). Analisis Perbandingan Kinerja Keuangan Perusahaan Telekomunikasi Yang Tercatat Di BEI (Studi Kasus Pada PT. Telekomunikasi Indonesia, Tbk. dan PT. Indosat Tbk. Periode 2006-2015). e Jurnal Riset Manajemen , 123-135.

Uyanto, S. S. (2009). Pedoman Analisis Data Dengan SPSS (3 ed.). Yogyakarta: Penerbit Graha IImu.

Wareza, M. (2018, November 09). Rekor! Dalam Setahun Lebih 50 Perusahaan IPO pada 2018. Dipetik Oktober 22, 2019, dari CNBC Indonesia: https://www.cnbcindonesia.com/ market/20181109125101-17-41373/rekor-dalamsetahun-lebih-50-perusahaan-ipo-pada-2018

Sunardi, N., \& Ula, L. N. R. (2017). Pengaruh BI Rate, Inflasi Dan Kurs Terhadap Indeks Harga Saham Gabungan (IHSG). Jurnal Sekuritas: Saham, Ekonomi, Keuangan dan Investasi, 1(2), 27-41.

Sunardi, N., \& Permana, R. D. I. (2019). Faktor-Faktor Yang Mempengaruhi Harga Saham Dan Dampaknya Pada Nilai Perusahaan (Studi Kasus pada Perusahaan Sub Sektor Pertambangan Minyak dan Gas Bumi yang Terdaftar di Bursa Efek Indonesia Tahun 2013-2017). JIMF (Jurnal IImiah Manajemen Forkamma), 2(2).

Sunardi, N. (2019). Profitabilitas, Likuiditas, Dan Multiplier Equity Pengaruhnya Terhadap Harga Serta Return Saham Pada Industri Manufaktur Tahun 20122017. INOVASI, 6(1), 58-73.

Sunardi, N. (2018). Kinerja Perusahan Pendekatan Du Pont System Terhadap Harga Dan Return Saham (Perusahaan yang tergabung dalam Industri Real Estate dan Properti yang terdaftar di Bursa Efek Indonesia Tahun 2011-2017). JIMF (Jurnal IImiah Manajemen Forkamma), 1(3). 